\title{
Movements and habitat use of reef manta rays off eastern Australia: offshore excursions, deep diving and eddy affinity revealed by satellite telemetry
}

\author{
F. R. A. Jaine ${ }^{1,2,3, *}$, C. A. Rohner ${ }^{1,2,3}$, S. J. Weeks ${ }^{1}$, L. I. E. Couturier ${ }^{2,4}$, \\ M. B. Bennett ${ }^{4}$, K. A. Townsend ${ }^{5,6}$, A. J. Richardson ${ }^{2,7}$ \\ ${ }^{1}$ Biophysical Oceanography Group, School of Geography, Planning and Environmental Management, \\ The University of Queensland, St Lucia, Queensland 4072, Australia \\ ${ }^{2}$ Climate Adaptation Flagship, CSIRO Marine and Atmospheric Research, Ecosciences Precinct, Dutton Park, \\ Queensland 4102, Australia
}

${ }^{3}$ Manta Ray and Whale Shark Research Centre, Marine Megafauna Foundation, Praia do Tofo, Inhambane, Mozambique ${ }^{4}$ School of Biomedical Sciences, and ${ }^{5}$ School of Biological Sciences, The University of Queensland, St Lucia, Queensland 4072, Australia

${ }^{6}$ Moreton Bay Research Station, The University of Queensland, Dunwich, Queensland 4183, Australia

${ }^{7}$ Centre for Applications in Natural Resource Mathematics, School of Mathematics and Physics, The University of Queensland, St Lucia, Queensland 4072, Australia

\begin{abstract}
Manta rays (Manta spp.) are plankton-feeding elasmobranchs classified as vulnerable to extinction on the IUCN Red List for Threatened Species. Despite increasing public and scientific interest in manta rays, major knowledge gaps concerning their movement ecology and dispersal capabilities remain. Here, we used pop-off satellite-linked archival transmitting tags to examine the horizontal movements and habitat use patterns of reef manta rays ( $M$. alfredi) departing Lady Elliot Island in the southern Great Barrier Reef, Australia. Tagged individuals moved across a latitudinal range of $1035 \mathrm{~km}$, travelling up to $2441 \mathrm{~km}$ in $118 \mathrm{~d}$, diving down to $294.5 \mathrm{~m}$ and venturing up to $155 \mathrm{~km}$ off the continental shelf. Using random walk simulations, we showed that manta rays spent significantly more time in an offshore region characterised by the mesoscale cyclonic Capricorn Eddy than would be expected by chance. A behaviour-switching state-space model suggested this area to be an important foraging ground for M. alfredi off eastern Australia. We document the movements of 1 individual using offshore waters between 2 known aggregation regions off eastern Australia. Reef manta rays thus not only occupy inshore continental shelf and shelf-edge waters but also use offshore environments to exploit productive hotspots and travel long distances. Our findings highlight the need to better understand their movement ecology for effective management.
\end{abstract}

KEY WORDS: Eddy - East Australian Current - Manta alfredi - Movements - Oceanography · Random walk $\cdot$ Satellite tracking $\cdot$ State-space analysis

\section{INTRODUCTION}

Understanding patterns of habitat use in vulnerable, large and highly mobile marine species is crucial to implementing effective, spatially explicit management strategies (Block et al. 2005, Graham et al.

\footnotetext{
${ }^{*}$ Corresponding author: fabrice@marinemegafauna.org
}

2012). This is especially true for plankton-feeding elasmobranchs that depend on their ability to locate minute and diffuse prey in a vast, dynamic and changing ocean (Richardson \& Schoeman 2004, Sims et al. 2006). Planktivorous elasmobranchs occur at low sub-population levels and for limited periods at 
inshore aggregation sites, where they can be readily observed. Therefore, obtaining daily data on their behaviour and identifying the driving forces behind their distributions are major challenges. Advances in the fields of bio-logging science, geographic information systems and ecological modelling have led to the increasing use of animal-attached sensors to remotely examine the movements, behaviour, physiology and/or biophysical habitat of a wide range of marine species (Cooke et al. 2004, Ropert-Coudert et al. 2009, Costa et al. 2012). Such studies have shed new light on the ecology of marine predators, unravelling a variety of behaviours ranging from localised movements made in relation to foraging opportunities (Sims et al. 2006, Papastamatiou et al. 2012) to larger-scale migrations (Bonfil et al. 2005, Block et al. 2011). In most cases, movements are driven by the availability of food resources (Zerbini et al. 2006, Anderson et al. 2011), species-specific physiologies (Pillans 2006) or the need to reproduce (Bonfil et al. 2005, Skomal et al. 2009).

Previous tracking studies have highlighted the importance of productive regions or features, such as oceanographic fronts and mesoscale eddies, in providing foraging opportunities (Polovina et al. 2000, Bailleul et al. 2010) for marine species, including plankton-feeding sharks (Sims \& Quayle 1998, Sims et al. 2003). Planktivorous elasmobranchs must acquire sufficient energy from minute and diffuse prey. As a result, bottom-up processes, whereby physical oceanographic features act to concentrate prey items in specific water bodies, are likely to influence predator distributions and their behavioural decisions. For instance, basking sharks Cetorhinus maximus congregate and feed on zooplankton blooms in frontal areas of the northeastern Atlantic (Sims \& Quayle 1998, Sims et al. 2003). However, the dispersal capabilities, behavioural ecology and habitat use patterns of other planktivorous elasmobranchs, such as manta rays (Manta spp.), are currently not well understood.

Manta rays are the largest of the batoid fishes and have a circumglobal distribution in tropical and subtropical waters (Marshall et al. 2009, Couturier et al. 2012). They are classified as vulnerable to extinction on the IUCN Red List of Threatened Species (Marshall et al. 2011a,b). Despite increasing public and scientific interest in manta rays, major knowledge gaps remain in their dispersal abilities, migratory ecology and drivers for their observed distributions. Until recently, most of the movement data available for manta rays had been derived from re-sightings of photographically identified individuals over rela- tively long time periods (e.g. Kashiwagi et al. 2010, Couturier et al. 2011) or from acoustic telemetry data (e.g. Dewar et al. 2008, Deakos et al. 2011). Such technologies provided the first insights into the movement ecology of manta rays, highlighting diurnal visitations of reef manta rays Manta alfredi to particular inshore sites (Dewar et al. 2008, Marshall 2008), movements between aggregation sites up to $500 \mathrm{~km}$ apart (Kashiwagi et al. 2010, Couturier et al. 2011) and seasonal migratory patterns in some regions (Anderson et al. 2011, Couturier et al. 2011). More recent telemetry studies have, for the first time, documented the movement patterns of both giant manta rays $M$. birostris and reef manta rays $M$. alfredi foraging in shallow habitats off the Yucatan Peninsula, Mexico, and in the Line Islands of the central Pacific, respectively (Graham et al. 2012, Papastamatiou et al. 2012). Such results have highlighted the importance of productivity blooms in inshore, coastal and coral reef ecosystems as key drivers for the spatial distributions and foraging habitats of manta rays (Graham et al. 2012, Papastamatiou et al. 2012).

In eastern Australia, M. alfredi occur at various localities along the coast, with some individuals seasonally migrating between sites up to $500 \mathrm{~km}$ apart (Couturier et al. 2011). One major aggregation site for M. alfredi is Lady Elliot Island (LEI) (Couturier et al. 2011, Jaine et al. 2012), a small coral cay in the southern Great Barrier Reef (GBR), located only a few kilometres from the continental shelf edge (see Fig. 1A). Here, $M$. alfredi occur year-round; they peak in austral autumn and winter, coincident with enhanced local productivity and foraging activity (Jaine et al. 2012). The presence of the mesoscale cyclonic Capricorn Eddy, which forms in the lee of the bathymetry off LEI because of the variability in strength of the southward-flowing East Australian Current (EAC) (Weeks et al. 2010), is known to trigger upwelling of cool, nutrient-rich sub-surface waters onto the shelf and around the Capricorn-Bunker reefs (Kleypas \& Burrage 1994, Weeks et al. 2010). Previously, the eddy has been suggested as an important driver of reef manta ray occurrence in the area and, more specifically, at LEI (Jaine et al. 2012). There, passive acoustic telemetry showed that individual manta rays can typically be observed daily over short time scales (i.e. up to $23 \mathrm{~d}$ ) and may then leave the surveyed area for extended periods of time (i.e. weeks to months) before returning to the site (Couturier 2013). To date, it is unknown where they go and what they do when not around LEI. In addition, it is unclear how M. alfredi disperse along the eastern Australian 
seaboard when undertaking long-distance movements $(>300 \mathrm{~km})$ and whether they commonly utilise specific migratory corridors, as observed in other species off eastern Australia (Bansemer \& Bennett 2011, Smith et al. 2012) and in other regions (Zerbini et al. 2006, Campana et al. 2011).

Here, we used satellite telemetry to explore the horizontal movements of individual $M$. alfredi departing LEI and gain insight into their movement patterns and habitat use in eastern Australia. We used random walk model simulations and a 2-state behaviour-switching state-space model (SSM) to test the hypotheses that (1) manta ray distributions within the southern GBR region are influenced by the presence of the nearby Capricorn Eddy and (2) movements of $M$. alfredi along the eastern Australian seaboard are directed towards productive regions. Our results suggest that reef manta rays not only occupy inshore continental shelf and shelfedge waters but also are capable of using offshore environments to exploit productive hotspots or travel long distances.

\section{MATERIALS AND METHODS}

\section{Manta ray tagging}

Fieldwork was conducted at LEI $\left(23^{\circ} 06^{\prime} \mathrm{S}\right.$, $152^{\circ} 42^{\prime}$ E) in the southern GBR. Ten Manta alfredi were fitted with pop-off satellite-linked archival transmitting (PSAT) tags during austral winter 2010 ( $\mathrm{n}=2)$, summer 2010-2011 ( $\mathrm{n}=2)$ and winter 2011 $(\mathrm{n}=6$; Table 1). Prior to tag deployment, each individual was identified, its size (disc width, $W_{\mathrm{D}}$ ) was estimated and its sex was determined using con- ventional manta ray photographic identification and laser photogrammetry techniques (Deakos 2010, Couturier et al. 2011, Marshall \& Pierce 2012). Tags were deployed on free-swimming individuals while free diving using a $320 \mathrm{~kg}$ Dyneema braid leader and an umbrella-shaped plastic dart inserted into the dorsal musculature, away from the body cavity, with a customised tagging pole. Eight manta rays (M1-M8) were equipped with Mk10 pop-up archival transmitting (Mk10-PAT) tags (Wildlife Computers), and manta rays 9 and 10 (M9 and M10) were equipped with Standard Rate XTags (Microwave Telemetry) (Table 1). Most tagged individuals were re-sighted within a few minutes post tag deployment, having resumed their previous foraging or cleaning activity and appearing to be unaffected by the devices.

\section{Tag programming and geolocation}

Mk10-PAT tags were programmed to record ambient light levels, sea temperature and pressure (to allow for calculations of swimming depth) at $30 \mathrm{~s}$ intervals and detach from the individual after 90 to 120 d. Depending on the tags, the binned data to be transmitted to the Argos satellite system (www. argos-system.org) upon release were summarised over time intervals of 6 or $12 \mathrm{~h}$. By default, X-Tags recorded the same parameters every $2 \mathrm{~min}$; however, based on the total deployment period of $120 \mathrm{~d}$, the transmitted data were summarised into 15 min bins. Upon release, 8 of the 10 deployed tags transmitted the summarised data successfully. Tags 66701 and 18379, deployed on M3 and M9, respectively, failed to transmit to the Argos system and were thus consid-

Table 1. Information on the deployment of pop-off archival satellite-transmitting tags on photographically identified, sexed and measured Manta alfredi. Tagging location was $23^{\circ} 06^{\prime} \mathrm{S}, 152^{\circ} 42^{\prime} \mathrm{E}$ for all mantas. $W_{\mathrm{D}}=$ disc width

\begin{tabular}{|c|c|c|c|c|c|c|c|c|c|c|}
\hline \multirow{2}{*}{$\begin{array}{l}\text { Manta } \\
\text { no. }\end{array}$} & \multirow{2}{*}{$\begin{array}{l}\text { Tag } \\
\text { no. }\end{array}$} & \multirow[t]{2}{*}{ Sex } & \multirow{2}{*}{$\begin{array}{c}\text { Size } \\
\left(W_{\mathrm{D}}, \mathrm{m}\right)\end{array}$} & \multirow[t]{2}{*}{ Tag type } & \multirow{2}{*}{$\begin{array}{l}\text { Pop-off } \\
\text { location }\end{array}$} & \multicolumn{2}{|c|}{ Date (dd/mm/yy) } & \multicolumn{2}{|c|}{ Duration (d) } & \multirow{2}{*}{$\begin{array}{c}\text { Tag } \\
\text { retrieved }\end{array}$} \\
\hline & & & & & & Tagging & Pop-off & Planned & Realised & \\
\hline M1 & 47726 & M & 3.50 & Mk10-PAT & $24^{\circ} 08^{\prime} \mathrm{S}, 153^{\circ} 16^{\prime} \mathrm{E}$ & $27 / 06 / 10$ & $30 / 08 / 10$ & 120 & 65 & Yes \\
\hline M2 & $60518 \mathrm{~A}$ & $\mathrm{~F}$ & 3.50 & Mk10-PAT & $22^{\circ} 25^{\prime} \mathrm{S}, 151^{\circ} 39^{\prime} \mathrm{E}$ & $28 / 06 / 10$ & $5 / 10 / 10$ & 120 & 99 & Yes \\
\hline M3 & 66701 & $\mathrm{~F}$ & 3.75 & Mk10-PAT & - & $5 / 01 / 11$ & - & 120 & - & - \\
\hline M4 & 66702 & $\mathrm{~F}$ & 3.50 & Mk10-PAT & $23^{\circ} 28^{\prime} \mathrm{S}, 151^{\circ} 26^{\prime} \mathrm{E}$ & $5 / 01 / 11$ & $11 / 02 / 11$ & 120 & 37 & No \\
\hline M5 & 66700 & M & 3.25 & Mk10-PAT & $23^{\circ} 40^{\prime} \mathrm{S}, 152^{\circ} 27^{\prime} \mathrm{E}$ & $19 / 06 / 11$ & $17 / 09 / 11$ & 90 & 90 & No \\
\hline M6 & 66703 & $\mathrm{~F}$ & 3.75 & Mk10-PAT & $23^{\circ} 30^{\prime} \mathrm{S}, 152^{\circ} 48^{\prime} \mathrm{E}$ & 19/06/11 & $15 / 10 / 11$ & 120 & 118 & Yes \\
\hline M7 & 66705 & $\mathrm{~F}$ & 4.25 & Mk10-PAT & $22^{\circ} 45^{\prime} \mathrm{S}, 151^{\circ} 41^{\prime} \mathrm{E}$ & 19/06/11 & $14 / 10 / 11$ & 120 & 117 & Yes \\
\hline M8 & $60518 \mathrm{~B}$ & $\mathrm{~F}$ & 4.00 & Mk10-PAT & $22^{\circ} 22^{\prime} \mathrm{S}, 153^{\circ} 30^{\prime} \mathrm{E}$ & $20 / 06 / 11$ & $18 / 09 / 11$ & 90 & 90 & Yes \\
\hline M9 & 18379 & M & 3.75 & X-Tag & - & $20 / 06 / 11$ & - & 120 & - & - \\
\hline M10 & 18380 & $\mathrm{~F}$ & 4.25 & $\mathrm{X}$-Tag & $24^{\circ} 09^{\prime} \mathrm{S}, 152^{\circ} 37^{\prime} \mathrm{E}$ & $20 / 06 / 11$ & $18 / 10 / 11$ & 120 & 120 & Yes \\
\hline
\end{tabular}


ered as 'lost'. An additional 6 tags washed ashore over a wide geographic range, from Maroochydore, Sunshine Coast (Queensland, 26.6 ${ }^{\circ} \mathrm{S}, 153.9^{\circ} \mathrm{E}$ ), to Shoalwater Bay (Queensland, 22.4 ${ }^{\circ} \mathrm{S}, 150.7^{\circ} \mathrm{E}$ ), and were physically retrieved by members of the public, allowing $100 \%$ of the higher-resolution archived raw data to be examined (Table 1). Transmissions from the remaining 2 tags (66700 and 66702) enabled varying amounts of data to be obtained and analysed (921 and 1565 messages, respectively).

Daily manta ray positions were estimated using the 'Track\&Loc' geolocation filter developed at Collecte Localisation Satellites (CLS, www.cls.fr), France. The algorithm relies on an SSM to represent process (movement) and observation uncertainty. Underwater positioning is achieved using an Ensemble Kalman filter applied to light-level measurements, with sea surface temperature (SST) and bathymetry data used to better constrain the tracks (Royer et al. 2005, Nielsen et al. 2006, Nielsen \& Sibert 2007, Royer \& Lutcavage 2008, 2009). This process allowed for the reconstruction of movement tracks based on daily position estimates. Tracks were then plotted and analysed for patterns of space utilisation, in ArcGIS 10 (ESRI, www.esri.com).

\section{Eddy affinity simulations}

To test the hypothesis that manta ray distributions within the southern GBR region are influenced by the presence of the cyclonic Capricorn Eddy, we used random walk model simulations to compare the proportion of time spent in the eddy region by 'real' tracked manta rays and model manta rays. For each tag, random movements of model manta rays were simulated in R (Ihaka \& Gentleman 1996) using the SDMTools package, such that each model ray featured the same starting location and total track length as the respective tracked manta ray. Distances between successive daily positions, termed steplengths, were randomly chosen from the real manta ray's step-length frequency distribution, and a random turn angle drawn from a uniform distribution was selected at the end of each step. Each step of the model manta rays was validated against a highresolution (i.e. $100 \mathrm{~m}$ ) digital bathymetry map generated using the gbr100 dataset (Beaman 2010) to preclude model rays from crossing land. The reorientation angle was replaced if the prior step was rejected. For each tag, movement tracks for 1000 model manta rays were simulated, and the proportion of time (in days) spent within the Capricorn Eddy region was recorded and compared to that of the real manta ray.

\section{Behavioural analysis}

A behaviour-switching SSM was fitted to movement data collected for real manta rays to discriminate behavioural activity from movement patterns and examine behavioural hotspots within the region of interest. Behaviour-switching SSMs have previously been used to successfully infer the 'hidden' behavioural state of an animal based on movement properties such as turn angles, step-lengths and autocorrelation in speed and direction derived from tracking data (Jonsen et al. 2005, Breed et al. 2009, 2012). Here, we fitted the 2-state switching correlated random walk model originally described by Jonsen et al. (2005) and refined in Breed et al. (2009) to our Manta alfredi data. This model has been successfully applied to various guilds of marine species to discriminate 'transiting' from 'foraging' behavioural states (e.g. pinnipeds: Breed et al. 2009, sea turtles: Maxwell et al. 2011, cetaceans: Bailey et al. 2009 and giant manta rays $M$. birostris: Graham et al. 2012). We implemented the model in $\mathrm{R}$ and WinBUGS (www.winbugs-development.org.uk). To fit the model, 2 Markov Chain Monte Carlo simulations were computed for 10000 iterations, with a 'burn-in' factor of 7000 and 'thinning' of 5, leaving 600 samples per chain as output to estimate each model parameter (see Breed et al. 2009). Model output was examined for differences between the autocorrelation parameter $\gamma$ and the behavioural state transition parameter $\alpha$ of the 2 states, indicative of true differentiation of the associated movement patterns.

\section{RESULTS}

Over the course of this study, tags remained attached to Manta alfredi for a mean period of $92 \mathrm{~d}$ ( $\pm 29 \mathrm{SD}$, range 37 to $120 \mathrm{~d}$ ). Five of the 8 tags that successfully transmitted to the Argos system reported on or near the programmed pop-up date, with 3 detaching prematurely for unknown reasons (Table 1). Overall, 5874 transmissions were received by the Argos system, with raw light-level data available for the 6 recovered tags. Geolocation estimates ranged in accuracy between 7.3 and $75.5 \mathrm{~km}^{2}$ (median $=18.4 \mathrm{~km}^{2} \pm 23.1 \mathrm{SD}$ ), depending on tag deployment duration and spatial extent of the movements recorded. 


\section{Spatial dynamics}

Tagged Manta alfredi were tracked over $736 \mathrm{~d}$, with movements recorded across a latitudinal range of $1035 \mathrm{~km}$ and with a mean track length of $1169 \mathrm{~km}$ \pm 640 SD (Fig. 1B). Track length varied among individuals, with M6 travelling the farthest $(2441 \mathrm{~km}$ in $118 \mathrm{~d})$, whereas M4 moved only $314 \mathrm{~km}$ in $37 \mathrm{~d}$ (Table 2). Female $M$. alfredi $(\mathrm{n}=6)$ dispersed farther than males $(\mathrm{n}=2)$ (Fig. 1C), despite no significant difference in their respective mean track lengths $(t=$ $-0.99, \mathrm{p}=0.38)$ and mean speeds $(t=-0.59, \mathrm{p}=0.58)$. Median speed across all tags, derived from daily move-steps, was $0.4 \mathrm{~km} \mathrm{~h}^{-1} \pm 0.5 \mathrm{SD}$, and maximum speed recorded was $3.5 \mathrm{~km} \mathrm{~h}^{-1}$ for M8 (Fig. 1D). Estimated swimming speeds across all tags were typically slow (i.e. $<0.75 \mathrm{~km} \mathrm{~h}^{-1}$ ) near LEI and directly off the shelf but increased when individuals dispersed to other regions. Daily maximum diving depths recorded by the PSAT tags revealed that the tracked rays dived down to $294.5 \mathrm{~m}$ (maximum depth range 56 to $294.5 \mathrm{~m}$ ), with greater maximum depths logged off the shelf near LEI (Fig. 1E).

Seven of the 8 tracked $M$. alfredi remained within the GBR region, while M10 moved off the shelf in waters over $2000 \mathrm{~m}$ deep and travelled southward to $28^{\circ} \mathrm{S}$ and back in $120 \mathrm{~d}$ (Fig. 1B). The southward leg of the journey was covered at $\sim 24 \mathrm{~km} \mathrm{~d}^{-1}$ (Fig. 1D). M10 then spent $~ 50$ d near the shelf edge off Moreton Island and North Stradbroke Island (NSI). Starting on Day 82, M10 moved $155 \mathrm{~km}$ eastward off the shelf before turning northward and broadly retracing its earlier southward movement, until the tag detached near LEI, coincident with the detection of the Capricorn Eddy and shelf intrusions in the satellite signal (Fig. 2). The other manta rays tagged at LEI (M1, M2 and M4-M8) all moved directly off the shelf near the tagging site, where they remained for a period of $50.7 \mathrm{~d} \pm 28.3 \mathrm{SD}$ before moving back onto the shelf and dispersing farther within the GBR. M1, M2 and M4-M8 moved up to $520 \mathrm{~km}$ from LEI (mean farthest linear distance from tagging site was $247 \mathrm{~km}$ $\pm 149 \mathrm{SD}$ in $77 \mathrm{~d} \pm 16 \mathrm{SD}$ ).

\section{Activity hotspots and eddy affinity}

Movement tracks recorded across all tags $(n=8)$ highlighted a major activity hotspot off the shelf near LEI (Fig. 1B), where the mantas spent $58.5 \%$ (range 2.5 to $87.5 \%$ ) of their time. There was a second hotspot off the shelf $\sim 100 \mathrm{~km}$ east of Moreton Island based on movement data for M10 only, which spent a considerable amount of time in this area ( $42 \%$ of total track).

Results from the random walk simulations varied among tags (Fig. 3). Only 2 of the 8 simulations were significant, where real manta rays spent significantly more time in the eddy region than the 1000 models (Table 3). However, since each simulation can be regarded as an independent test of whether manta rays spent more time than random in the eddy, results from the 8 tests, each with 1000 model iterations, were combined using a proportion test. Together, these simulations revealed that real manta rays spent significantly more time in the eddy region than model rays $(\mathrm{p}<0.001)$.

\section{Behaviour}

The 2-state behaviour-switching SSM discriminated transiting and foraging activity from the tracking data (Fig. 1F). Of the total tracking positions $(\mathrm{n}=$

Table 2. Movement metrics for 8 Manta alfredi tracked by pop-off archival satellite-transmitting tags. Minimum horizontal displacement $=$ distance between tag deployment and detachment locations. Speed is estimated from daily move step-lengths. Foraging and transiting behaviours are inferred from state-space analysis of movement data

\begin{tabular}{|c|c|c|c|c|c|c|c|c|c|c|c|}
\hline \multirow{3}{*}{$\begin{array}{l}\text { Manta } \\
\text { no. }\end{array}$} & \multirow{3}{*}{$\begin{array}{c}\text { Min. horizon- } \\
\text { tal displace- } \\
\text { ment }(\mathrm{km})\end{array}$} & \multirow{3}{*}{$\begin{array}{l}\text { Track } \\
\text { length } \\
(\mathrm{km})\end{array}$} & \multirow{3}{*}{$\begin{array}{l}\text { Max. } \\
\text { depth } \\
(\mathrm{m})\end{array}$} & \multirow{2}{*}{\multicolumn{2}{|c|}{$\begin{array}{l}\text { Step-length } \\
\left(\mathrm{km} \mathrm{d}^{-1}\right)\end{array}$}} & \multicolumn{2}{|c|}{ Speed $\left(\mathrm{km} \mathrm{d}^{-1}\right)$} & \multicolumn{2}{|c|}{ Time (\%) } & \multicolumn{2}{|c|}{ Mean speed $\left(\mathrm{km} \mathrm{h}^{-1}\right)$} \\
\hline & & & & & & Median & Max. & Fora- & Tran- & Fora- & Tran- \\
\hline & & & & Mean & Max. & & & ging & siting & ging & siting \\
\hline M1 & 63 & 523 & 283 & 8.2 & 31.9 & 0.3 & 1.3 & 100.0 & 0.0 & 0.3 & - \\
\hline M2 & 218 & 1023 & 167 & 10.3 & 34.7 & 0.3 & 1.4 & 76.8 & 23.2 & 0.3 & 0.7 \\
\hline M4 & 137 & 314 & 56 & 8.5 & 61.0 & 0.2 & 2.5 & 78.4 & 21.6 & 0.2 & 0.9 \\
\hline M5 & 53 & 1089 & 96 & 12.0 & 63.6 & 0.4 & 2.7 & 82.4 & 17.6 & 0.5 & 0.6 \\
\hline M6 & 69 & 2441 & 140 & 20.7 & 75.5 & 0.6 & 3.1 & 41.5 & 58.5 & 0.6 & 1.2 \\
\hline M7 & 183 & 1243 & 196 & 10.6 & 43.7 & 0.3 & 1.8 & 66.7 & 33.1 & 0.4 & 0.7 \\
\hline M8 & 210 & 1365 & 294.5 & 15.2 & 84.4 & 0.6 & 3.5 & 26.7 & 73.3 & 0.5 & 0.8 \\
\hline M10 & 7 & 1351 & 97.2 & 11.1 & 31.6 & 0.4 & 1.3 & 0.0 & 100.0 & - & 0.5 \\
\hline
\end{tabular}



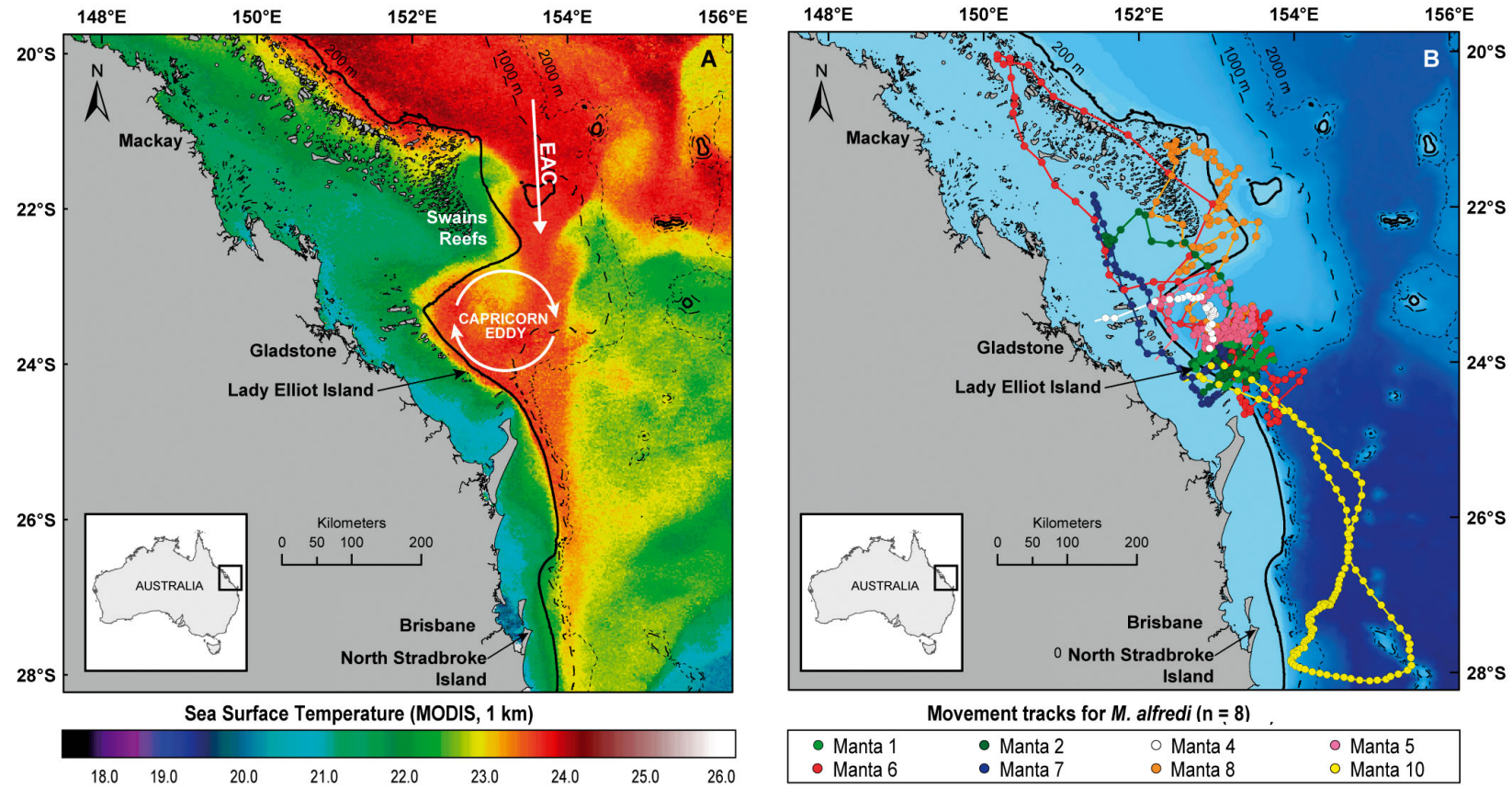

$\begin{array}{lllllllll}18.0 & 19.0 & 20.0 & 21.0 & 22.0 & 23.0 & 24.0 & 25.0 & 26.0\end{array}$
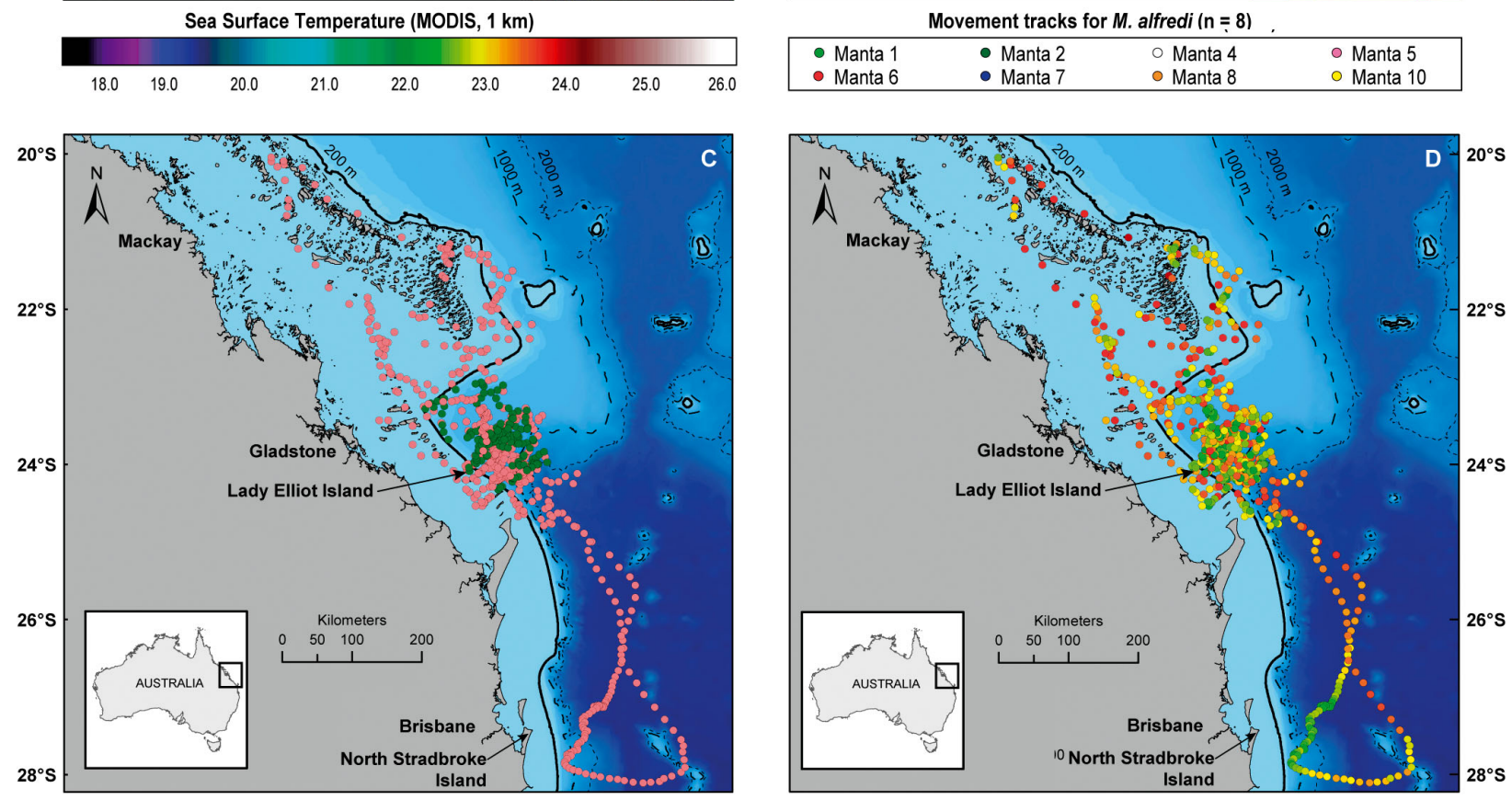

ex of tracked $M$. alfredi

- Female $(n=6) \quad$ Male $(n=2)$

Estimated speed $\left(\mathbf{k m} \cdot \mathrm{h}^{-1}\right)$

0.25

0.75

1.0

$2.0 \quad 3.0$

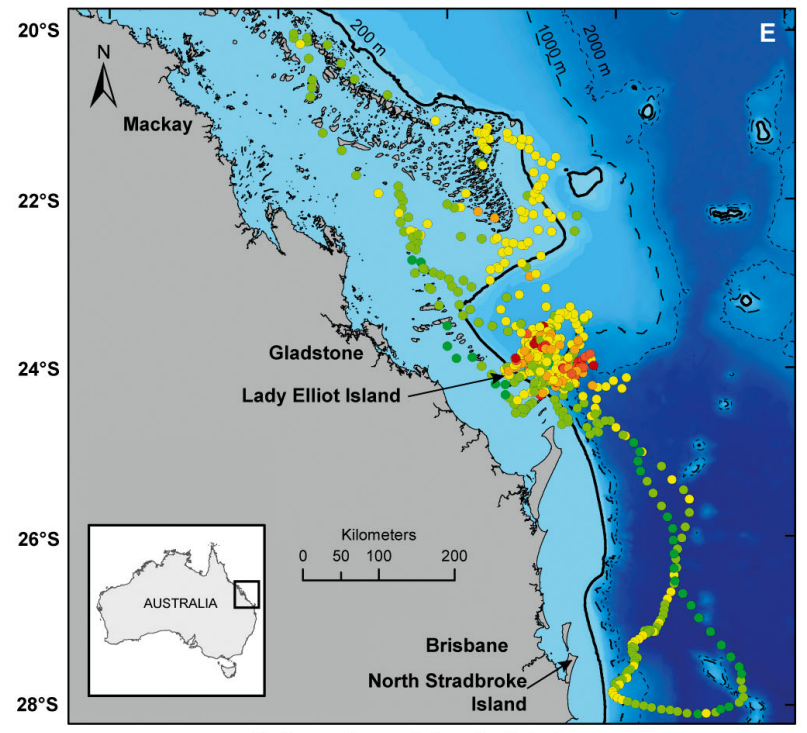

Daily maximum diving depth $(\mathrm{m})$

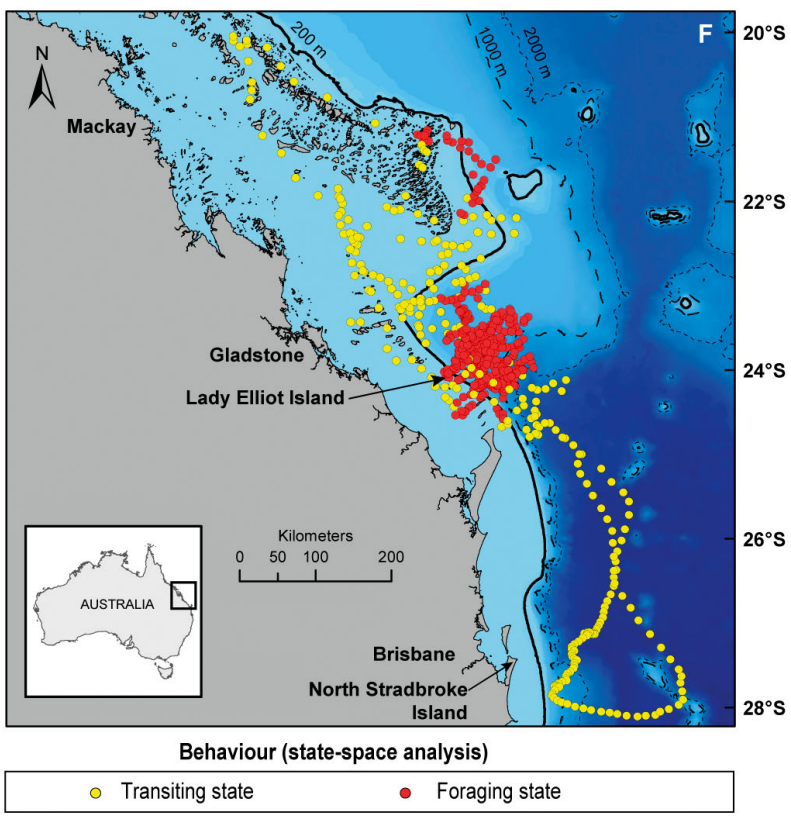


Table 3. Time spent by each tracked Manta alfredi in the Capricorn Eddy region and output from the random walk simulations for each track, including numbers of successes, failures and resulting p-value for the test comparing the proportion of time spent in the eddy by tracked and model manta rays. Successful and unsuccessful simulations refer to the numbers of model rays that successfully (or unsuccessfully) spent as much time in the eddy region as real manta rays

\begin{tabular}{|lccccc|}
\hline $\begin{array}{l}\text { Manta } \\
\text { ray }\end{array}$ & $\begin{array}{c}\text { Days in eddy } \\
\text { region }\end{array}$ & $\begin{array}{c}\text { Time in eddy } \\
\text { region (\%) }\end{array}$ & $\begin{array}{c}\text { Successful model } \\
\text { simulations }\end{array}$ & $\begin{array}{c}\text { Unsuccessful model } \\
\text { simulations }\end{array}$ & p-value \\
\hline M1 & 55 & 84.6 & 101 & 899 & 0.101 \\
M2 & 65 & 65.6 & 154 & 846 & 0.154 \\
M4 & 32 & 86.5 & 92 & 908 & 0.092 \\
M5 & 79 & 87.8 & 16 & 984 & 0.016 \\
M6 & 55 & 46.6 & 40 & 960 & 0.040 \\
M7 & 71 & 60.7 & 125 & 875 & 0.125 \\
M8 & 30 & 33.3 & 328 & 672 & 0.328 \\
M10 & 3 & 2.5 & 647 & 353 & 0.647 \\
Total & 390 & 58.5 & 1503 & 6497 & $<0.001$ \\
\hline
\end{tabular}

736), $53.5 \%$ were determined as the 'foraging' state, while the 'transiting' state made up the remaining $46.5 \%$. Results revealed important foraging activity across all but one (M10) track in the eddy region, offshore of LEI. The foraging behavioural state made up $\sim 95 \%$ of locations recorded in the eddy region. A secondary foraging location off the Swain Reefs was also highlighted based on tracking data for M8, which made up $3.6 \%$ of total locations across all tags.

\section{DISCUSSION}

Using satellite telemetry and spatial analyses, we showed that reef manta rays not only occupy inshore continental shelf and shelf-edge waters but also use offshore environments to exploit productive hotspots or undertake long-distance movements. All but 1 manta ray tagged in the southern GBR spent a substantial amount of time in the Capricorn Eddy region, off the continental shelf. A behavioural analysis of the tracking data further suggested that they may use this area as a foraging ground. Using offshore waters, 1 manta ray travelled $520 \mathrm{~km}$ southward to another known aggregation region before returning to the tagging region.

\section{Spatial dynamics}

Reef manta rays tagged in the southern GBR moved across a wide geographical area along the eastern Australian coastline, covering a latitudinal range of $1035 \mathrm{~km}$ (between $20^{\circ} \mathrm{S}$ and $28^{\circ} \mathrm{S}$ ). Although minimum horizontal displacements (i.e. distances between tagging and pop-off locations) were relatively small and suggestive of localised movements of individuals (Table 2), track reconstruction revealed more extensive movements. Reef manta rays travelled up to $2441 \mathrm{~km}$ in $118 \mathrm{~d}$ and dispersed as far as $520 \mathrm{~km}$ from the tagging site, occupying both regional shelf and offshore waters. This is, to date, one of the largest directional movements recorded and the first horizontal movement tracks obtained for Manta alfredi using satellite telemetry.

Tracked reef manta rays displayed some degree of affinity to the southern GBR. Despite recording some of the longest movement tracks and moving the farthest away from LEI, M6 and M10 eventually returned to the southern GBR towards the end of their respective tagging periods. The 6 other tagged individuals remained within the southern GBR region during their tracking periods. These results suggest some degree of fidelity to the region,

Fig. 1. Study region showing (A) typical regional oceanographic setting (Moderate Resolution Imaging Spectroradiometer [MODIS] sea surface temperature, June 2010), marked by the southward flow of the core East Australian Current (EAC) and the cyclonic Capricorn Eddy (CE) forming in the lee of the shelf topography; (B) movement tracks for Manta alfredi tagged at Lady Elliot Island $(\mathrm{n}=8)$, with daily position estimates (filled circles); $(\mathrm{C})$ spatial dynamics of male $(\mathrm{n}=2)$ and female $(\mathrm{n}=6)$ $M$. alfredi; (D) swimming speed estimated from daily position estimates; (E) daily maximum diving depth for tracked $M$. alfredi $(n=8)$; and $(F)$ behaviour inferred from state-space analysis of the tracking data. Blue shading in $(B-F)$ indicates water depth, where lightest colours are depths $<200 \mathrm{~m}$, and darkest colours are depths $>2000 \mathrm{~m}$ 

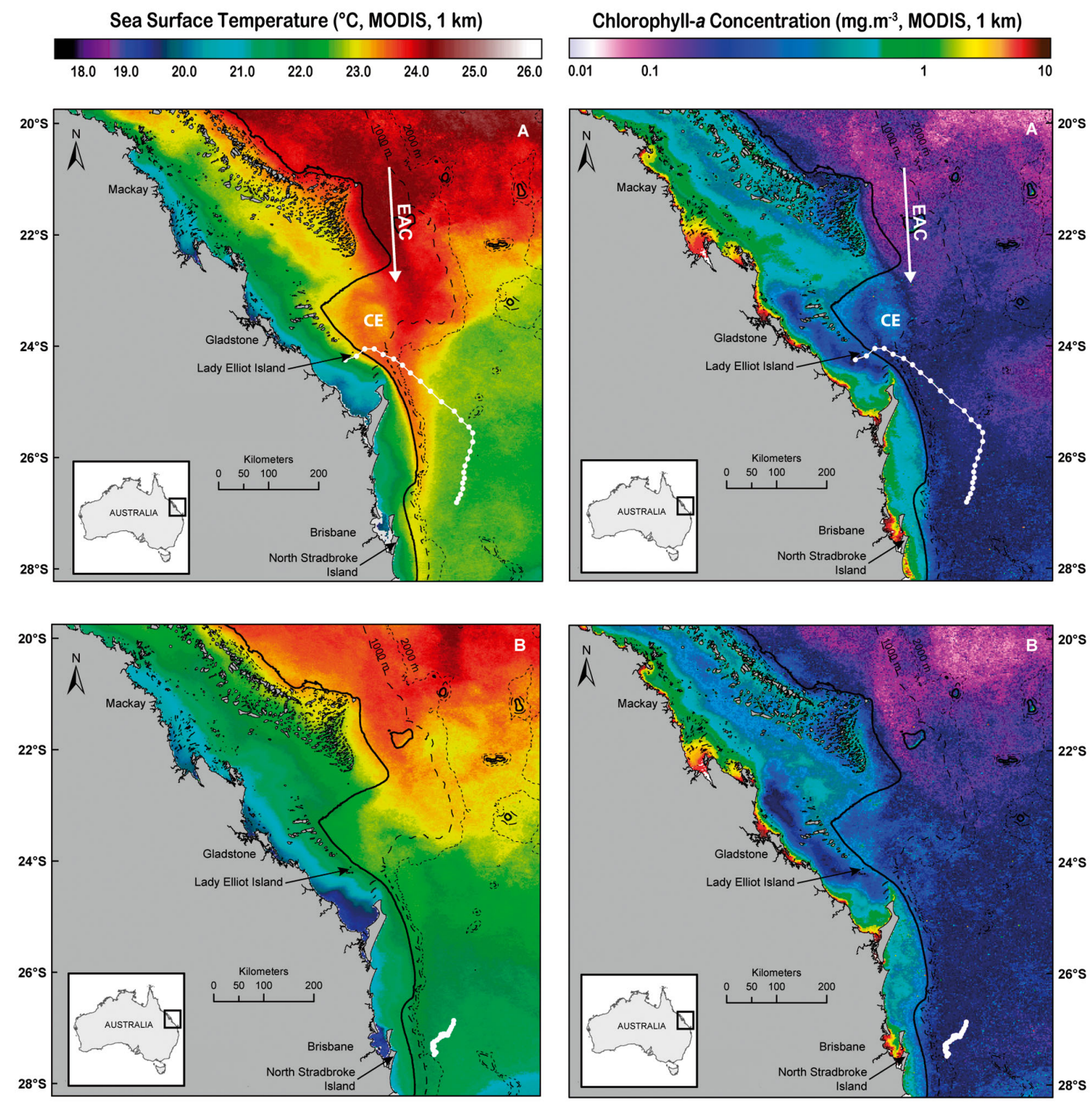

Fig. 2 (this page and next page). Spatial and temporal dynamics of Manta alfredi M10 in relation to the oceanographic conditions. Moderate Resolution Imaging Spectroradiometer (MODIS) sea surface temperatures (left column panels) and chl a concentrations (right column panels) are presented for movements of M10 (white track) tracked between (A) June 19 and July 18 , 2011, (B) July 19 and August 18, 2011, (C) September 19 and October 18, 2011, and (D) November 19 and December $18,2011$. Data are presented at monthly intervals for clarity only, although dynamics at finer temporal resolutions have been investigated and did not differ. 'CE' marks the presence of the Capricorn Eddy feature in the satellite signal, and white arrows denote intrusions of upwelled oceanic waters onto the shelf. EAC = East Australian Current

which supports previous findings by Couturier et al. (2011). Using photographic identification techniques, Couturier et al. (2011) documented dispersal by $M$. alfredi to other known aggregation sites along the eastern Australian seaboard, likely associated with seasonal migratory movements. Similarly, van
Duinkerken (2010) identified the dispersal of individual $M$. alfredi along the southern Mozambican coast. There, acoustically tagged $M$. alfredi typically showed high fidelity to particular sites along the coast and occasionally dispersed throughout the entire $95 \mathrm{~km}$ long acoustic array. Long-distance movements and 

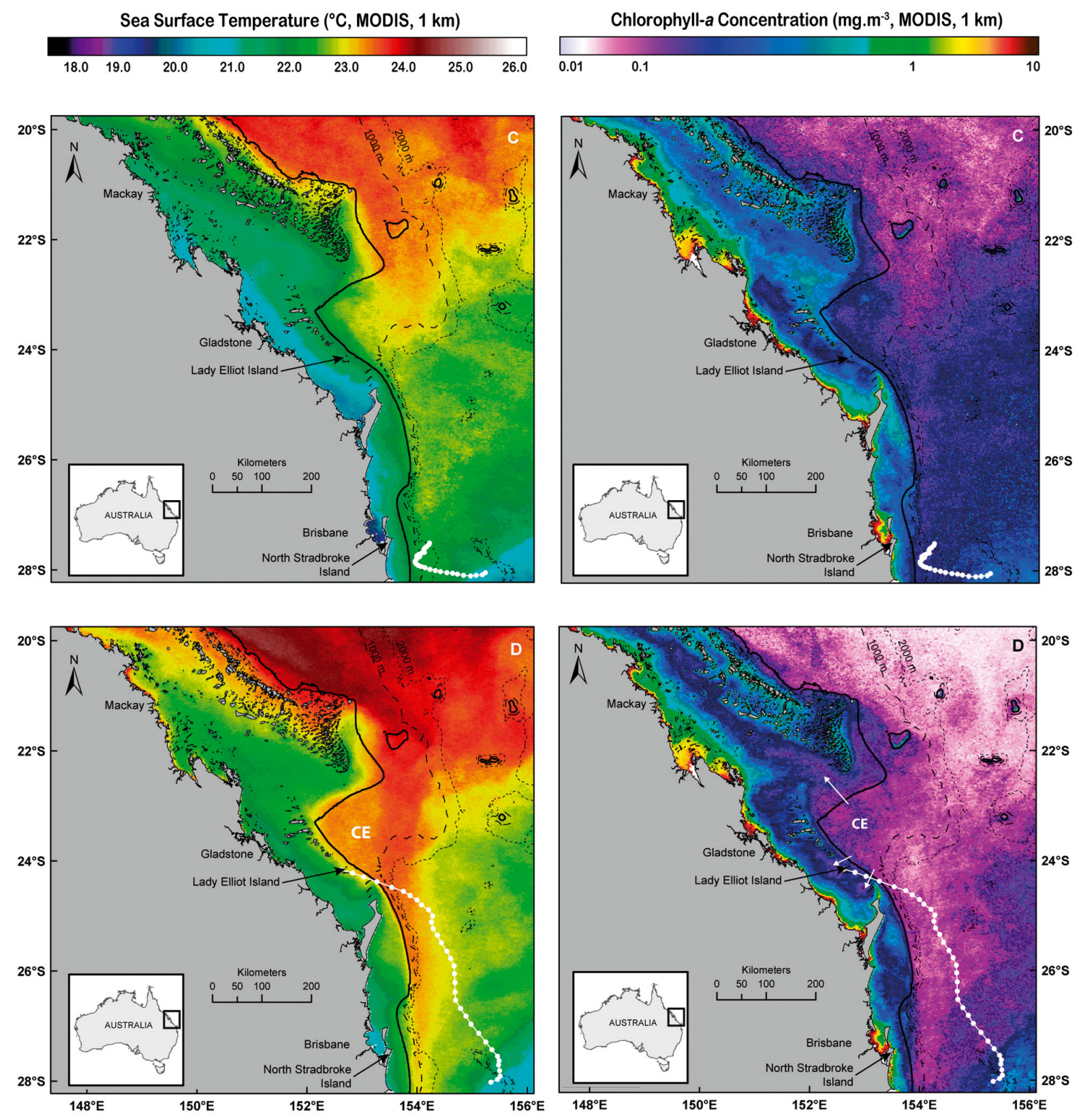

Fig. 2 (continued)

migrations are typically attributed to the need to reproduce and exchange genetic material between members of separate populations (Bonfil et al. 2005, Skomal et al. 2009) or the search for abundant food resources (Zerbini et al. 2006, Anderson et al. 2011). The question of sex-biased dispersal in $M$. alfredi could not be assessed here because of our limited data, despite tagged females noticeably dispersing farther than the 2 males.

The mean and maximum speeds observed here, derived from daily distances travelled, were similar to those observed in other $M$. alfredi sub-populations (e.g. van Duinkerken 2010). Despite the low spatial and temporal resolution of the collected data, results suggested that reef manta rays can travel distances of up to $\sim 85 \mathrm{~km} \mathrm{~d}^{-1}$, averaging speeds of $\sim 3.5 \mathrm{~km} \mathrm{~h}^{-1}$. In the future, the use of additional sensors (e.g. accelerometers) will help collect more accurate, higher-resolution swimming speed data, which may provide additional insights into the movement ecology of these planktivorous elasmobranchs. 

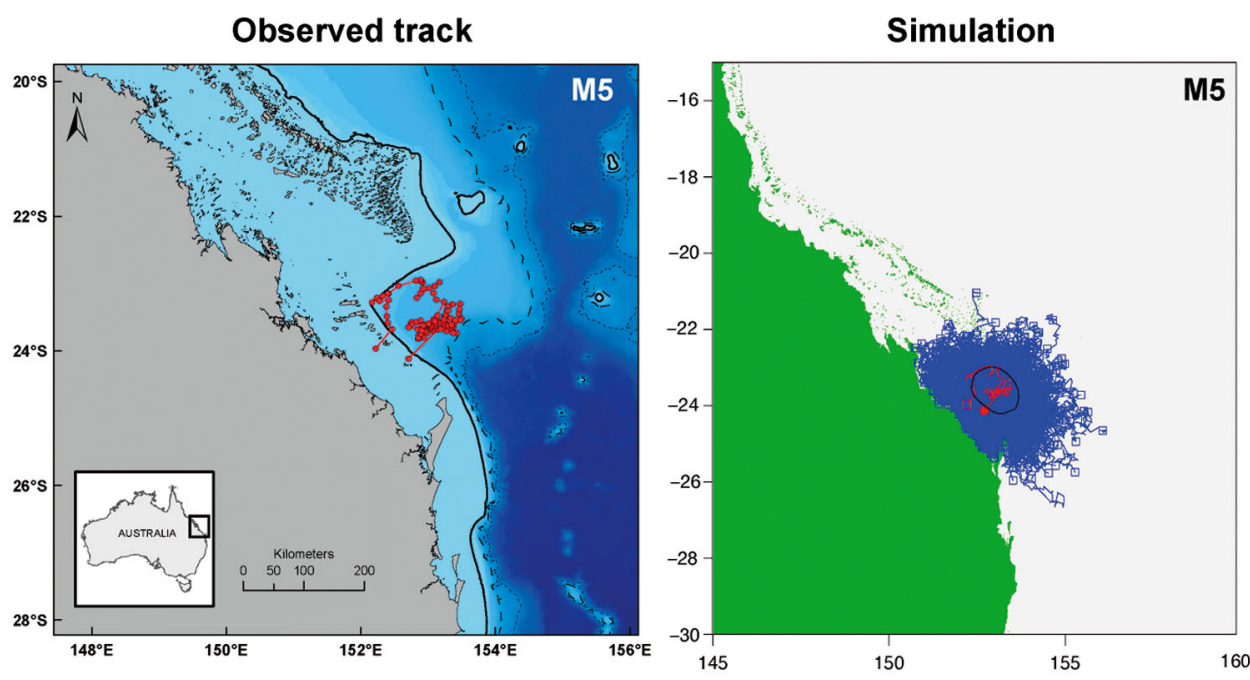

Time in Eddy region

$\operatorname{M5}(p<0.016, n=1000)$
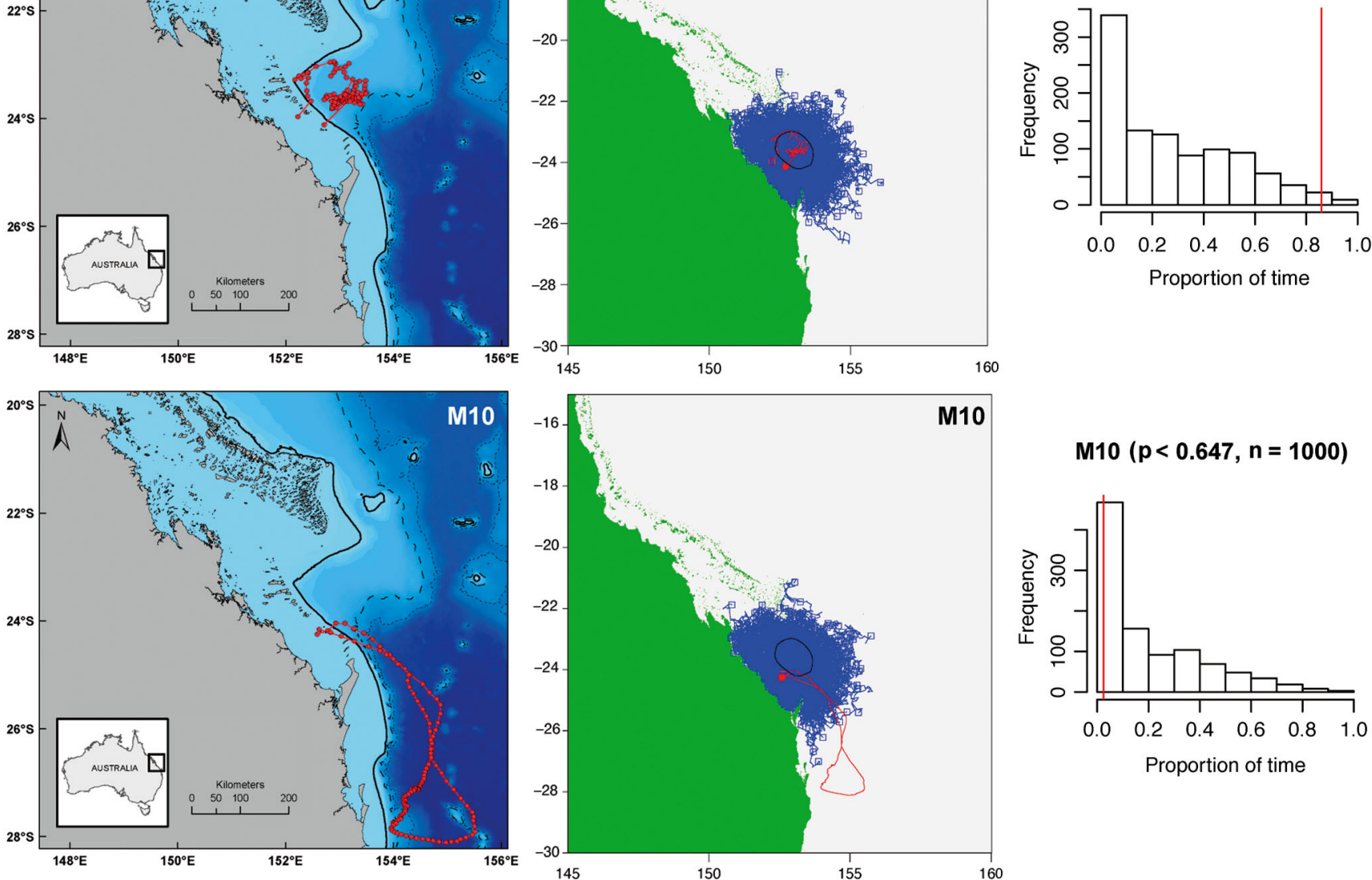

$M 10(p<0.647, n=1000)$

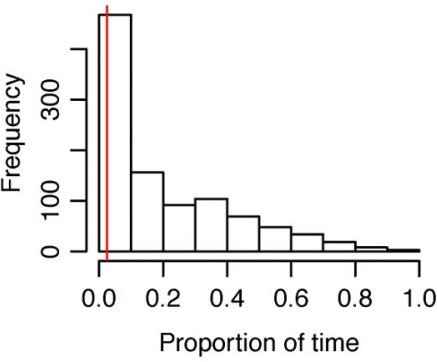

Fig. 3. Representative unsuccessful (M5) and successful (M10) random walk simulations. Panels in the first column, 'observed track', present the movement track (red line) and daily position estimates (filled circles) for each individual manta ray. The second column, 'simulation', shows the geographically unconstrained 1000 random walks (blue) generated for each respective Manta alfredi (red) from the step-length frequency distribution and the typical Capricorn Eddy region (black circle) ( $x$ - and $y$-axes are degrees of longitude and latitude, respectievly). The third column, 'time in eddy region', indicates the proportion of time spent in

the eddy region by 1000 unconstrained random walks (white bars) compared to that of each respective $M$. alfredi (red line)

\section{Eddy affinity and offshore foraging}

The offshore Capricorn Eddy region was the primary site of occupancy for most satellite-tagged rays. Mesoscale eddies, such as the Capricorn Eddy, stimulate and redistribute biological production in the ocean, thus creating attractive pelagic habitats for free-ranging, higher trophic level marine organisms (Chelton et al. 2011, Godø et al. 2012). Our results suggest that manta rays may exploit offshore mesoscale eddies for foraging purposes and corroborate several other studies that showed the importance of mesoscale eddies as offshore foraging grounds for a variety of marine species (e.g. seabirds: Weimerskirch et al. 2004, Cotté et al. 2007; pinnipeds: Bailleul et al. 2010, Dragon et al. 2010; cetaceans: Woodworth et al. 2012).

Cyclonic eddies are known to enhance nutrient enrichment and subsequent primary production in subtropical western boundary systems (Falkowski et al. 1991, McGillicuddy et al. 1998, 2007, Weeks et al. 2010). In the case of the Capricorn Eddy, turbulent momentum exchanges with the strong southwardflowing EAC that flows along the edge of the GBR shelf produce a lateral stress on the mass of water in the lee of the Swain Reefs. This drives cyclonic (clockwise) and radially outward eddy circulation, leading to the upwelling of cooler, nutrient-enriched water in the centre of the eddy (Bakun 1996, Weeks et al. 2010). The resulting upwelled waters flow 
coastward in the near-surface upper layer, eventually accumulating near LEI and the CapricornBunker reefs. Interestingly, the primary activity area of tagged and presumed foraging Manta alfredi in this study was the southeastern portion of the eddy region, most likely because of the consistently enhanced productivity in this area triggered by eddy dynamics.

Reef manta rays tagged in the southern GBR spent extended periods off the shelf, undertaking deep dives, presumably foraging, and occasionally moving back onto the shelf. This result supports findings from Braun et al. (2014), who documented offshore deep-diving behaviour of satellite-tracked $M$. alfredi directly adjacent to shallow coral reefs. Together, these results challenge previous assumptions that reef manta rays primarily rely on inshore productivity blooms as foraging habitats and highlight that regional and mesoscale oceanographic investigations are needed to better understand habitat use patterns of these large, free-ranging planktivores. Moreover, a recent study by Couturier et al. (2013) suggested that $M$. alfredi in eastern Australia do not predominantly rely on near-surface zooplankton prey during coastal feeding events and suggested that deep and/or demersal zooplankton may be an important part of the diet. The movement patterns and depths recorded by tagged $M$. alfredi in this study, suggestive of extensive off-shelf foraging and greater diving activity in a region of welldocumented upwelling (Kleypas \& Burrage 1994, Weeks et al. 2010), may thus provide additional insights into the foraging ecology of the species in eastern Australia. More detailed analyses of the recovered high-resolution depth data will help further explore the diving behaviour and vertical habitat use of $M$. alfredi.

\section{Movements between aggregation regions}

A census for manta ray sightings in eastern Australia provided the first insight into the geographical distribution and movement patterns of Manta alfredi in the region (Couturier et al. 2011). Results from the photographic survey revealed that $M$. alfredi is present along $\sim 3000 \mathrm{~km}$ of coastline, from Torres Strait in northern Queensland to Sydney in central New South Wales, and highlighted several inshore locations as key aggregation sites for the species (Couturier et al. 2011). More importantly, some M. alfredi appear to migrate between waters off NSI, Byron Bay or the Solitary Islands in spring-summer (mid-
October to mid-April) and the southern GBR in autumn-winter (Couturier et al. 2011, Jaine et al. 2012). Here, we found that 1 reef manta ray moved southward from LEI to near NSI and returned to the southern GBR in $120 \mathrm{~d}$, providing the first movement track for $M$. alfredi travelling between known aggregation regions along the eastern Australian seaboard.

The movement patterns of this 1 individual indicated that reef manta rays can use offshore waters, including the EAC flow, to travel up and down the eastern coast of Australia (Fig. 2). Despite the single observation here, 35 individual $M$. alfredi have been repeatedly re-sighted previously between LEI and the southern sites of NSI, Byron Bay and the Solitary Islands (Couturier et al. 2011), and it is thus likely that more individuals undertake similar movements because of the variability and seasonality in the EAC flow. For example, during summer reef manta rays are common in the southern portion of the coast (Couturier et al. 2011), coincident with increased EAC intensity and subsequent enhanced biological productivity (Oke \& Middleton 2000, Roughan \& Middleton 2004, Nieblas et al. 2009). In winter, when the EAC flow is weaker and the core EAC waters do not extend as far south, reef manta ray numbers peak in the southern GBR (Jaine et al. 2012), coincident with a clear satellite signal of the Capricorn Eddy and associated enhanced productivity (Kleypas \& Burrage 1994, Weeks et al. 2010).

Although limited to 1 individual, the observed movements of M10, which travelled between the southern GBR and NSI, could suggest that enhanced productivity off these sites may act as a driver for $M$. alfredi migrations. The individual, tracked over winter-spring 2011, moved to spend a considerable amount of time off the shelf-edge near NSI. Although the behavioural SSM analysis revealed transitingonly behaviour for this individual, most likely because of the very directional nature of its movement patterns, the extended period spent off the shelf edge off NSI suggests otherwise. Despite anecdotal records of $M$. alfredi foraging in NSI coastal waters, the NSI study site is primarily known as a popular manta ray cleaning station. However, while no published study has yet documented upwelling frequency and productivity in the area, in situ oceanographic data clearly show that upwelling events occur and are most pronounced with increased EAC intensity in spring-summer (S. J. Weeks pers. obs.). The individual slowed down when approaching the shelf-edge region off NSI and spent the following $\sim 50 \mathrm{~d}$ in the area before moving farther 
offshore and eventually returning to the southern GBR. While remotely sensed SSTs and chl a concentrations for the corresponding period do not show strong inshore EAC flow or sharp fronts off NSI, typically indicative of inshore upwelling processes, the departure from and subsequent return to LEI appear to coincide with increased intensity of the Capricorn Eddy and shelf intrusions, as seen in the satellite signal (Fig. 2). It is thus possible that this individual may have been searching for other productive hotspots along the eastern Australian seaboard.

\section{CONCLUSIONS}

This study presents the first satellite-derived movement dataset for the reef manta ray Manta alfredi in Australia. In addition to showing that $M$. alfredi move across relatively large scales (i.e. $>500 \mathrm{~km}$ ), this study highlights that reef manta rays spend considerable time in offshore pelagic waters. Our results show that eastern Australian manta rays have an affinity for a relatively stable mesoscale cyclonic eddy, which may comprise an important foraging ground for the species. Further, we document the movements of 1 individual between 2 popular aggregation regions off the eastern Australian seaboard using offshore waters. Together, our findings suggest that $M$. alfredi may commonly use offshore waters to undertake movements between aggregation sites and exploit ephemeral productivity hotspots. Although threats to $M$. alfredi are comparatively low in eastern Australia, these findings highlight the need for enhanced knowledge about the movements of manta rays to be considered when implementing regional management strategies.

Acknowledgements. We thank Dr. J. Brunnschweiler and Dr. C. Huveneers for providing feedback on earlier versions of the manuscript. We also thank Dr. G. Breed for help with interpretation of the output from the behaviour-switching SSM, as well as the 'Track\&Loc' team at CLS, Argos, France, for assistance with geolocation analysis and PSAT tag data monitoring. We gratefully acknowledge the NASA Ocean Biology Processing Group for provision of Moderate Resolution Imaging Spectroradiometer satellite data. We are grateful to the various helpers who contributed to the fieldwork, including C. Garraway, A. Rakovski, R. Jeffery, K. Fiora, C. Ansell, R. Cheseldene-Culley, A. Donnelly and M. Romanovski. This study was supported by Australian Research Council Linkage Projects grant LP110100712, a research grant from the PADI Foundation, Sibelco, an anonymous donor, Earthwatch Institute Australia and Lady Elliot Island Eco Resort. Fieldwork was conducted under Great Barrier Reef Marine Park permit G09/29853.1 and ethics approval SBMS/071/08/SEAWORLD.

\section{LITERATURE CITED}

Anderson RC, Adam MS, Goes JI (2011) From monsoons to mantas: seasonal distribution of Manta alfredi in the Maldives. Fish Oceanogr 20:104-113

Bailey H, Mate BR, Palacios DM, Irvine L, Bograd SJ, Costa DP (2009) Behavioural estimation of blue whale movements in the Northeast Pacific from state-space model analysis of satellite tracks. Endang Species Res 10: 93-106

Bailleul F, Cotté C, Guinet C (2010) Mesoscale eddies as foraging area of a deep-diving predator, the southern elephant seal. Mar Ecol Prog Ser 408:251-264

Bakun A (1996) Patterns in the ocean: ocean processes and marine population dynamics. University of California Sea Grant, San Diego, California, USA, in cooperation with Centro de Investigaciones Biologicas de Noroeste, La Paz, Baja California Sur

Bansemer CS, Bennett MB (2011) Sex- and maturity-based differences in movement and migration patterns of grey nurse shark, Carcharias taurus, along the eastern coast of Australia. Mar Freshw Res 62:596-606

Beaman RJ (2010) Project 3DGBR: a high-resolution depth model for the Great Barrier Reef and Coral Sea. Marine and Tropical Sciences Research Facility, Project 2.5i.1a Final Report, Cairns, Australia, available at www. deepreef.org/bathymetry/65-3dgbr-bathy.html

$>$ Block BA, Teo SLH, Walli A, Boustany A and others (2005) Electronic tagging and population structure of Atlantic bluefin tuna. Nature 434:1121-1127

Block BA, Jonsen ID, Jorgensen SJ, Winship AJ and others (2011) Tracking apex marine predator movements in a dynamic ocean. Nature 475:86-90

Bonfil R, Meyer M, Scholl M, Johnson R and others (2005) Transoceanic migration, spatial dynamics, and population linkages of white sharks. Science 310:100-103

Braun CD, Skomal GB, Thorrold SR, Berumen ML (2014) Diving behavior of the reef manta ray links coral reefs with adjacent deep pelagic habitats. PLoS One 9(2), e88170

Breed GA, Jonsen ID, Myers RA, Bowen WD, Leonard ML (2009) Sex-specific, seasonal foraging tactics of adult grey seals (Halichoerus grypus) revealed by state-space analysis. Ecology 90:3209-3221

> Breed GA, Costa DP, Jonsen ID, Robinson PW, MillsFlemming J (2012) State-space methods for more completely capturing behavioral dynamics from animal tracks. Ecol Model 235-236:49-58

Campana SE, Dorey A, Fowler M, Joyce W, Wang Z, Wright D, Yashayaev I (2011) Migration pathways, behavioural thermoregulation and overwintering grounds of blue sharks in the northwest Atlantic. PLoS ONE 6:e16854

> Chelton DB, Gaube P, Schlax MG, Early JJ, Samelson RM (2011) The influence of nonlinear mesoscale eddies on near-surface oceanic chlorophyll. Science 334:328-332

> Cooke SJ, Hinch SG, Wikelski M, Andrews RD, Kuchel LJ, Wolcott TG, Butler PJ (2004) Biotelemetry: a mechanistic approach to ecology. Trends Ecol Evol 19:334-343

Costa DP, Breed GA, Robinson PW (2012) New insights into pelagic migrations: implications for ecology and conservation. Annu Rev Ecol Evol Syst 43:73-96

Cotté C, Park YH, Guinet C, Bost CA (2007) Movements of foraging king penguins through marine mesoscale eddies. Proc Biol Sci 274:2385-2391

Couturier LIE (2013) Population ecology and biology of the 
reef manta ray Manta alfredi in eastern Australia. PhD thesis, School of Biomedical Sciences, The University of Queensland, Brisbane, available at http://espace.library. uq.edu.au/view/UQ:302657

> Couturier LIE, Jaine FRA, Townsend KA, Weeks SJ, Richardson AJ, Bennett MB (2011) Distribution, site affinity and regional movements of the manta ray, Manta alfredi (Krefft, 1868), along the east coast of Australia. Mar Freshw Res 62:628-637

$>$ Couturier LIE, Marshall AD, Jaine FRA, Kashiwagi T and others (2012) Biology, ecology and conservation of the Mobulidae. J Fish Biol 80:1075-1119

> Couturier LIE, Rohner CA, Richardson AJ, Marshall AD and others (2013) Stable isotope and signature fatty acid analyses suggest reef manta rays feed on demersal zooplankton. PLoS ONE 8:e77152

> Deakos MH (2010) Paired-laser photogrammetry as a simple and accurate system for measuring the body size of freeranging manta rays Manta alfredi. Aquat Biol 10:1-10

$>$ Deakos MH, Baker JD, Bejder L (2011) Characteristics of a manta ray Manta alfredi population off Maui, Hawaii, and implications for management. Mar Ecol Prog Ser 429:245-260

> Dewar H, Mous P, Domeier M, Muljadi A, Pet J, Whitty J (2008) Movements and site fidelity of the giant manta ray, Manta birostris, in the Komodo Marine Park, Indonesia. Mar Biol 155:121-133

> Dragon AC, Monestiez P, Bar-Hen A, Guinet C (2010) Linking foraging behaviour to physical oceanographic structures: southern elephant seals and mesoscale eddies east of Kerguelen Islands. Prog Oceanogr 87:61-71

Falkowski PG, Ziemann D, Kolber Z, Bienfang PK (1991) Role of eddy pumping in enhancing primary production in the ocean. Nature 352:55-58

Godø OR, Samuelsen A, Macaulay GJ, Patel R and others (2012) Mesoscale eddies are oases for higher trophic marine life. PLoS ONE 7:e30161

Graham RT, Witt MJ, Castellanos DW, Remolina F, Maxwell S, Godley BJ, Hawkes LA (2012) Satellite tracking of manta rays highlights challenges to their conservation. PLoS ONE 7:e36834

Ihaka R, Gentleman R (1996) R: a language for data analysis and graphics. J Comput Graph Stat 5:299-314

Jaine FRA, Couturier LIE, Weeks SJ, Townsend KA, Bennett MB, Fiora K, Richardson AJ (2012) When giants turn up: sighting trends, environmental influences and habitat use of the manta ray Manta alfredi at a coral reef. PLoS ONE 7:e46170

Jonsen ID, Flemming JM, Myers RA (2005) Robust statespace modeling of animal movement data. Ecology 86: 2874-2880

Kashiwagi T, Ito T, Sato F (2010) Occurrences of reef manta ray, Manta alfredi, and giant manta ray, $M$. birostris, in Japan, examined by photographic records. Rep Jpn Soc Elasmobranch Stud 46:20-27

> Kleypas J, Burrage D (1994) Satellite observations of circulation in the southern Great Barrier Reef, Australia. Int J Remote Sens 15:2051-2063

Marshall AD (2008) Biology and population ecology of Manta birostris in southern Mozambique. PhD thesis, School of Biomedical Sciences, The University of Queensland, Brisbane, available at http://espace.library. uq.edu.au/view/UQ:160974

Marshall AD, Pierce SJ (2012) The use and abuse of photographic identification in sharks and rays. J Fish Biol 80:
1361-1379

Marshall A, Compagno L, Bennett M (2009) Redescription of the genus Manta with resurrection of Manta alfredi (Krefft, 1868) (Chondrichtyes; Myliobatoidei; Mobulidae). Zootaxa 2031:1-28

Marshall AD, Kashiwagi T, Bennett MB, Deakos M and others (2011a) Manta alfredi. In: IUCN Red List of Threatened Species version 2012-1 (accessed on February 15, 2013)

Marshall A, Bennett M, Kodja G, Hinojosa-Alvarez S and others (2011b) Manta birostris. In: IUCN Red List of Threatened Species version 2012-1 (accessed on February 15, 2013)

Maxwell SM, Breed GA, Nickel BA, Makanga-Bahouna J and others (2011) Using satellite tracking to optimize protection of long-lived marine species: olive ridley sea turtle conservation in central Africa. PLoS ONE 6:e19905

> McGillicuddy DJ, Robinson AR, Siegel DA, Jannasch HW and others (1998) Influence of mesoscale eddies on new production in the Sargasso Sea. Nature 394:263-266

McGillicuddy DJ, Anderson LA, Bates NR, Bibby T and others (2007) Eddy/wind interactions stimulate extraordinary mid-ocean plankton blooms. Science 316: 1021-1026

Nieblas AE, Sloyan BM, Hobday AJ, Coleman R, Richardson AJ (2009) Variability of biological production in low wind-forced regional upwelling systems: a case study off southeastern Australia. Limnol Oceanogr 54:1548-1558

Nielsen A, Sibert J (2007) State-space model for light-based tracking of marine animals. Can J Fish Aquat Sci 64: 1055-1068

Nielsen A, Bigelow KA, Musyl MK, Sibert J (2006) Improving light-based geolocation by including sea surface temperature. Fish Oceanogr 15:314-325

Oke PR, Middleton JH (2000) Topographically induced upwelling off eastern Australia. J Phys Oceanogr 30: 512-531

> Papastamatiou YP, DeSalles PA, McCauley DJ (2012) Arearestricted searching by manta rays and their response to spatial scale in lagoon habitats. Mar Ecol Prog Ser 456: 233-244

Pillans RD (2006) The physiological ecology of the bull shark Carcharhinus leucas in the Brisbane River. PhD thesis, School of Integrative Biology, The University of Queensland, Brisbane, available at http://espace.library.uq. edu.au/view/UQ:158284

Polovina JJ, Kobayashi DR, Parker DM, Seki MP, Balazs GH (2000) Turtles on the edge: movement of loggerhead turtles (Caretta caretta) along oceanic fronts, spanning longline fishing grounds in the central North Pacific, 1997-1998. Fish Oceanogr 9:71-82

Richardson AJ, Schoeman DS (2004) Climate impact on plankton ecosystems in the northeast Atlantic. Science 305:1609-1612

> Ropert-Coudert Y, Beaulieu M, Hanuise N, Kato A (2009) Diving into the world of biologging. Endang Species Res 10:21-27

> Roughan M, Middleton JH (2004) On the East Australian Current: variability, encroachment, and upwelling. J Geophys Res 109:C07003, doi:10.1029/2003JC001833

> Royer F, Lutcavage M (2008) Filtering and interpreting location errors in satellite telemetry of marine animals. J Exp Mar Biol Ecol 359:1-10

Royer F, Lutcavage M (2009) Positioning pelagic fish from sunrise and sunset times: complex observation errors call 
for constrained, robust modeling. In: Nielsen JL, Fragoso N, Lutcavage M, Arrizabalaga H, Hobday A, Sibert J (eds) Tagging and tracking of marine animals with electronic devices. Reviews: methods and technologies in fish biology and fisheries. Springer, Dordrecht, p 323-341

Royer F, Fromentin JM, Gaspar P (2005) A state-space model to derive bluefin tuna movement and habitat from archival tags. Oikos 109:473-484

Sims D, Quayle V (1998) Selective foraging behaviour of basking sharks on zooplankton in a small-scale front. Nature 393:460-464

Sims DW, Southall EJ, Richardson AJ, Reid PC, Metcalfe JD (2003) Seasonal movements and behaviour of basking sharks from archival tagging: no evidence of winter hibernation. Mar Ecol Prog Ser 248:187-196

Sims DW, Witt MJ, Richardson AJ, Southall EJ, Metcalfe JD (2006) Encounter success of free-ranging marine predator movements across a dynamic prey landscape. Proc R Soc Lond B Biol Sci 273:1195-1201

Skomal GB, Zeeman SI, Chisholm JH, Summers EL, Walsh HJ, McMahon KW, Thorrold SR (2009) Transequatorial migrations by basking sharks in the western Atlantic Ocean. Curr Biol 19:1019-1022

Editorial responsibility: Nicholas Tolimieri,

Seattle, Washington, USA
Smith JN, Grantham HS, Gales N, Double MC, Noad MJ, Paton D (2012) Identification of humpback whale breeding and calving habitat in the Great Barrier Reef. Mar Ecol Prog Ser 447:259-272

van Duinkerken DI (2010) Movements and site fidelity of the reef manta ray, Manta alfredi, along the coast of southern Mozambique. Masters thesis, Utrecht University

- Weeks SJ, Bakun A, Steinberg CR, Brinkman R, HoeghGuldberg O (2010) The Capricorn Eddy: a prominent driver of the ecology and future of the southern Great Barrier Reef. Coral Reefs 29:975-985

- Weimerskirch H, Le Corre M, Jaquemet S, Potier M, Marsac F (2004) Foraging strategy of a top predator in tropical waters: great frigatebirds in the Mozambique Channel. Mar Ecol Prog Ser 275:297-308

- Woodworth PA, Schorr GS, Baird RW, Webster DL and others (2012) Eddies as offshore foraging grounds for melon-headed whales (Peponocephala electra). Mar Mamm Sci 28:638-647

> Zerbini AN, Andriolo A, Heide-Jørgensen MP, Pizzorno JL and others (2006) Satellite-monitored movements of humpback whales Megaptera novaeangliae in the Southwest Atlantic Ocean. Mar Ecol Prog Ser 313: 295-304

Submitted: June 11, 2013; Accepted: June 10, 2014

Proofs received from author(s): August 29, 2014 